\title{
ISSUES IN HEALTHY AGEING AMONG AFRICAN RURAL WOMEN
}

${ }^{* 1}$ Prof. Okonkwor Oby. C. N.

(P.hD, Faoses, Fifho, Fica, Fipmd, Oia, Wmga,Mstan,Mnim,Mspan, Mnipr, Lsm)

${ }^{* 1}$ Department Of Human Kinetics \& Health Education, Nnamdi Azikiwe University, Akwa, NIGERIA

Abstract:

Life expectancy has increased considerably and people are continually getting aware of the need to stay young, healthy, active and alive. In order to achieve these as one ages, we need to adopt a healthy life style and diet suitable for each stage of later life. The African culture has its uniqueness due to many factors including the extended family system (EFS) where one is totally dependent on the off-spring and relatives at old age. On the other hand women generally live longer than men thereby creating a situation that provides more old women and widows in the society. Furthermore, the same African culture (like the Igbos of Nigeria) do not encourage old widows to remarry or socialize, thereby placing more economic, sociopsychological and health challenges on the aged women especially in the rural setting where the younger ones have abandoned their villages to migrate to urban areas. The purpose of this paper is to discuss the issues of healthy aging among the African rural women. It is never too early or too late to work for healthy aging. Therefore, the health, social, psychological, economic and emotional aspect of life-style adjustment for aging .gracefully and happily shall be discussed. The paper ends with functional recommendations as strategies to equip individuals with useful skills for healthy, happy, active life as one ages.

Keywords:

Impulsive buying behavior, situational factors, demographic impact, internal factors, post purchase dissonance

Cite This Article: Prof. Okonkwor Oby. C.N, "ISSUES IN HEALTHY AGEING AMONG AFRICAN RURAL WOMEN" International Journal of Research - Granthaalayah, Vol. 3, No. 6(2015): 45-65. DOI: https://doi.org/10.29121/granthaalayah.v3.i6.2015.3000.

\section{INTRODUCTION}

The road to good health and longevity is not easy but it is attainable. Your destiny is in your hand; take control of your life and be in charge. I have discussed many issues concerning health and longevity in public lectures, newspaper columns, books, and in the internet. To the glory of God so many took advantage of the information and are now singing a new song with wonderful testimonies. Your story shall not be different. I pray it is going to be the same with you. Amen! The World Health Organization (WHO) has defined health as a state of total physical, mental, social, psychological well-being; not just the absence of disease. Definitely everyone would like to live a healthy long life but not many can. This is why many Nigerians spend thousands or millions of Naira in order to live even an extra year, which often may become impossible due to 


\section{INTERNATIONAL JOURNAL of RESEARCH -GRANTHAALAYAH

factors like unhealthy life style and bad feeding. Is it possible to achieve long, healthy life and enjoy ones old age? The answer is yes, all other accidental deaths removed. This is why John 3:1-2 tell us:

"Behold I wish above all things that thou mayest prosper and be in good health, even as thy soul prospereth".

Our life has no duplicate. To make a good and healthy life is exclusively our individual race. I am going to take you on a ride. That ride is not a site-seeing ride in a park, nor is it on a long trip to a distant city. It is a health trip that will ever change your health for better, fulfilling, enjoyable and longer life. This health information shall base more on PREVENTION - which is known to be better than cure.

To the glory of God, I am a survivor of a deadly tumor and my sister, Chinwe survived a breast cancer. Another Chinwe-my roommate at University of Lagos, Nigeria is a breast cancer survivor; Seline Opara from Owerri, Nigeria survived a crippling diabetes and is managing her cancer complications better. It may be important to mention in addition that my mother is over 75 years and she is stronger and healthier than most people at their fifties. My husband retired from public service over fifteen years ago and his health status can be compared to most people in their prime youth. These are not mere stories to convert 'reluctant souls'. They are really verifiable facts. It is Gods will that you live and live your life to the fullest. Life is to be enjoyed, not endured- Deuteronomy 30:19 says that "I have set before you life and death, blessing and curse, therefore choose life, that both thou and thy seed may live".

In John 10:10, the Bible says:-

"I have come that you might have life and that you may have it abundantly".

God who created us designs that we live and not just live, but to live it in abundance and to the fullest. I know that the first point of prayer of over $90 \%$ is "GOOD HEALTH AND LONG LIFE". It is my major point of prayer too. The only difference is that some people pray but do not translate their prayer into practical use. Now let us put our prayers, dreams and desires into practice. COME ON BOARD! LET”S RIDE ON!!

By way of my brief background, apart from having sound $1^{\text {st }} 2^{\text {nd }} 3^{\text {rd }}$ and Doctorate degrees in Human Biology, Health and Physical Education (Human Kinetics) and Sports Sciences from a reputable University (UNILAG), I have successfully operated Health and Fitness Centers within and outside Nigeria. I am also an American certified Fitness Instructor in addition to my qualification as a Therapeutic Dance Choreographer (TDS) from RIO School of Dance, Brazil. I am not just a theorist; I am a PRACTICAL PROFESSIONAL.

It is not the strongest species that survive nor the most intelligent; but the most responsive to change. Charles Darwin (1859) 


\section{INTERNATIONAL JOURNAL of RESEARCH -GRANTHAALAYAH

\section{EXPECTATIONS OF THE AGED}
a. To live as long as possible, at least, until the advantage of death seems to outweigh the burdens of life.
b. To get more rest, relaxation and sound refreshing sleep.
c. To remain active participants in personal and group affairs in either operational or supervisory roles-rather than complete idleness and indifference.
d. To safeguard and even strengthen any prerogatives acquired in a long life (e.g. skills, possessions, rights, authority and prestige);
e. To meet death, when necessity requires it, as honorably as possible, without too much suffering and with maximal prospects for a robust and attractive generation even after.
f. To join the angels in paradise after a very long and fulfilled life.

\section{CHALLENGES OF THE AGED}

Social and biochemical challenges of the aged necessitate that there is a need to improve quality of life and prevent or reduce dependency in an ageing population. Increasing age is associated with increasing risk of disability e.g. hearing and vision, loss of bone tissue, reduction in muscle mass, reduced respiratory function, decline in cognitive function, rise in blood pressure and muscular degeneration which pre-disposes to conditions such as osteoporosis, heart diseases, dementia and blindness. Hearing diseases especially Otosclerosis (degenerative change associated with advancing age) have been observed to take an increasing toll on the ageing population.

Some of the common diseases that affect the elderly are:

Heart attack, high Blood Pressure, Stroke, diabetes, arthritis, rheumatism, loss of memory, high cholesterol, to mention but a few.

Whereas, the various outward manifestations of the passage of years on an individual can be said to be essentially anatomical, however, these changes are as a result of both the physiological and biochemical molecular occurrences.

\section{SIGNS OF AGING}

\section{PHYSICAL SIGNS}

Include but not limited to, wrinkles, skin fold, bending of body frame, discolouration of skin, dullness and redness of eye, puffy eyes, declining mobility, etc.

\section{PSYCHOLOGICAL/MENTAL SIGNS AND SYMPTOMS}

Poor memory, low self-esteem, childish behaviour at a very advanced age; deterioration in mental ability, anxiety, depression disorganization of emotional and mental balance. 


\section{INTERNATIONAL JOURNAL of RESEARCH -GRANTHAALAYAH

SOCIAL SIGNS/SYMPTOMS

Social isolation, poor interpersonal relationship, continued decline in social outings as age increases and so on.

\section{HEALTH SIGNS/SYMPTOMS}

98 percent of health problems escalate with increasing age including impotence, low libido and poor sexual desire.

\section{AFRICAN SOCIETY AND CULTURE}

This book focuses on the aged as a social category in Africa, South of the Sahara: It views Africa from the perspective of a cultural entity. That is, it believes that Africans share a remarkable cultural Unity, This perspective has developed out of the findings of anthropologists who conducted ethnographic searches among the various societies in the continent during the last century. The French anthropologist Jacques Maquet 1972:4) notices the peculiar African cultural unity and said:

Life-styles and work-styles are the heart of the matter sustaining; human behaviour and things made in the social group. It is not the sunshine or the black skin that gives the impression of African unity. ... This unity, strongly yet vaguely experienced by the traveller returning to Africa, is a cultural unity.

It should quickly be noted that though this book emphasizes African cultural unity, it does not deny the continents diversity. In fact, anthropological studies have also shown the differences among various societies of Africa. Thus, Otite (1978/9) notes:

The major language distribution on African continent-Semitic, Hamitic, Hottentot, Bantu, Sudanic and Bushmen-together with their subdivisions as vital parts of cultures and as mechanisms for transmitting philosophies and thoughts through the generations, further testify to the high degree of cultural pluralism in Africa.

African peoples may be sub-divided into several (broad groups defined according to their primary economic activity (e.g. hunters, farmers, pastoralist); language family (e.g Khoisan, Bantu), or another criterion (Stock, 1995). Therefore, the cultural element in Africa, as elsewhere belongs to the diversity of institutional' order whose second part is social (Otite, 1978).

Despite cu1tura1pluraity, African societies generally share similar social and cultural heritage. Stock (1995) observes that "African society may be seen as a nested hierarchy - hundreds of ethnic groups belonging to several large groups all of which share a common African identity". The African cultural unity is so obvious that Maquet (1972) calls It "Africanity".

Otite (1978) also notes however, that the Africaness in the societies and cultures of Africa is perhaps inherent in their common characteristics. Indeed, Blyden and others have led the way in emphasizing the distinctness of Africa cultures and societies. According to Blyden (1908) 


\section{INTERNATIONAL JOURNAL of RESEARCH -GRANTHAALAYAH

Africans are 'Co-operative not egotistic or individualistic. We and not I is the law of African life". The over-riding principle according to Blyden, is not that "all yours are mine" but "all mine are yours". This life principle forms the "basis of all ethical thought in Africa. In the African scheme of ethics, a self-seeking and self-asserting individual does not fit in (Blyden, 1908; Ottenberg and Ottenberg, 1960; Mair, 1964; Otite, 1978).

To really understand the African cultural unity, there is the need to describe several constituent elements of the African identity. The African society is indeed, a system of mutually benefiting reciprocities (Otite, 1978). To an average African, society exists for the good of all its members in a system of role enforcements. This involve a myriad of reciprocal relationships. There is a very close link between the principle of exchange and reciprocity. Thus, Otite (1978) observes:

There is high moral torte closing to a religion as part of the African System of multiple reciprocities. Even economic exchanges have a social context and a moral tone. This morality and religion in African system of multidirectional reciprocities is reinforced by a system of mutual benefits direct or indirect, in the context of brotherhood ideology.

In fact, it has been observed that the interplay between the moral element and the principle of reciprocal relationships is critical in distinguishing what is African.

Furthermore, respect for wise and judicious authority is an African attribute (Onwuejeogwu 1975, Stock 1995). In the African society, the chief, chosen by elders for his strength, wisdom and integrity, is a spiritual as well as political figure, whose leadership determines the prosperity, health and safety of the group. At the village level the authority of community elders, acting as guardians of the common welfare, is respected.

Also, the African society has its social welfare as part of the family etiquette (Blyden, 1908). Also in any African community, everybody - old and young, male and female-has food to eat and clothes to wear. In times of local scarcity, there is always the will and the capacity for generous hospitality. In fact, in African society, the family and local community are responsible for their weak members, their dependent old and young members, and the sick. It is believed that any need is a vital social responsibility. In African society "big men" with political and economic power are expected to use it their resources generously for the benefit of their followers. Their support takes the form of gifts during festivals, financial support for marriages etc.

In addition, Africans conceptualize the relations between humankind and nature in a way very different from that of Western societies. While the Christian theology tends to see humankind as outside and above nature, African traditional religions emphasize that spiritual forces are manifest everywhere in the environment (Ottenberg and Ottenberg, 1960; Mbiti, 1969; Idowu, 1973; Stock, 1995). Gods and spirits are associated with such landmarks as rock outcrops and tree groves. Gods and spirits are thought to be concerned about the daily affairs of humans. The deities are honoured in sacrifices and ceremonies, often undertaken at specific times of the year 


\section{INTERNATIONAL JOURNAL of RESEARCH -GRANTHAALAYAH

and conducted by priests devoted to their worship (Ottenberg and Ottenberg, 1960; Mbiti, 1969; Idown, 1973).

Also crucial to the expression of Africa identity are arts especially, sculpture, music and storytelling (Stock, 1995). Artistic expression serves a variety of purposes ranging from the veneration of ancestors and glorification of rulers, to education of the young. In fact, anthropologists have observed that there is virtually no African society where arts are not found. In some, art objects are produced for religious purposes, while in others they are meant for entertainment and education-two overlapping artistic traditions have been identified in Africa. These are court art which are done by professionals at the behest of chiefs and the popular culture in which all ordinary Africans participate to a greater or lesser extent as the case may be. Realizing the peculiarity of African identity and cultural unity, both the African elite and non elite have since the last century joined hands in a crusade against loss of their Africaness. This, according to Otite (1978), had led to many conceptions of what is African. For example, the concept of Negritude is one of the concepts used to recapture the African past and its present.

Negritude is a socio-political and cultural ideology which expresses the value of African colour and culture (Otite, 1978). It is a counter-acculturation movement which ends up in defence of African ancestral cultures and traditions. Similarly, the sense of blackism as co-extensive with African culture, was given a new lift by the second World Black and African Festival of Arts and Culture held in Lagos, Nigeria in 1975. This festival was meant to revive and reaffirm the culture of black people all over the world. This festival demonstrated African identity and cultural unity.

\section{GENDER GAP IN AGEING AND LONGEVITY}

Generally, aging in men and women may be compared to a process that takes place in a brand new car. The new car is faultless at first. With use, the wear and tear set in naturally, except the owner is conscientious and observant in maintaining the car.

If well-maintained, the car will continue to look new and last much longer than newer cars bought several months or years after it.

Human beings are born young, vibrant, resourceful and full of vitality. With time, both men and women grow old at different rates until they reach senility and die. The circumstances that surround human growth and development definitely impinge on the rate of aging for both men and women.

The foregoing chapters have profusely commented on the agents of fast aging. It is therefore, sufficient here to reiterate that these agents include:

Poverty - a demon that hits men and women hard and opens them up for further devastation by aging. 


\section{INTERNATIONAL JOURNAL of RESEARCH -GRANTHAALAYAH

Social

Careless habits - eating and drinking habits, sexual habits and the habits of laziness can accelerate aging.

Natural biological/physiological phenomena that promote aging regardless of appeals from manmade agents

Psychological losses and other daily worries that drain vitality and promote aging.

Since the focus of this chapter is on whether women grow old faster than men, it is essential to isolate the factors that influence the aging rate of women and discuss them: The following factors are pertinent.
a. Monthly cycles Childbirth
b. Psychological dependence and independence

\section{MONTHLY CYCLES}

Women are fearfully and wonderfully made in the image of God their creator, a bit different from men. We are made under normal circumstances to loose blood in a cyclical form at puberty till menopause. Every normal woman at puberty goes through this experience of menstruation which can be strength- reducing, distressing and stressful. In some women, the menstrual period comes with headaches, acute menstrual pains and a lot of discomfort. This process wears women out, and coupled with poverty, it can accelerate aging.

Ingrid Trobisch (1996) says the ovulation in women makes them exhibit distressful moods. It also means that hormonal discharges unreplaced, bring about aging in women faster than men.

\section{CHILDBIRTH}

Childbirth is a process that makes women, young and old depending on care during gestation and after birth, experience declining vitality.

Childbirth can bring untold hardship on women especially where balanced diet, medical attention and psychological support are lacking. An undernourished pregnant woman may age faster and even die soon after childbirth. A malnourished woman may have difficulty in bringing forth children into the world during birth. This could cause mutilation or fracture of the bone and even tear of the vagina which may be difficult to put together causing faster aging in women than men.

Peter Medawar in the 1950s, developed a theory of harmful mutations of humans during midlife. Thomas Kirkwood in the 1970s hypothesised that the more energy one spends bearing children the less one has for other metabolic feats. The idea here is that the woman's body does fall prey to decline and disease after childbirth. It is difficult to defend against the mutations that cause 


\section{INTERNATIONAL JOURNAL of RESEARCH -GRANTHAALAYAH

aging since the reproductive organs become weak naturally. For example the elasticity of the womb, tiredness due to loss of blood at every childbirth, mental and psychological fits may contribute immensely to aging.

The babies need to be breastfed for healthy growth. This entails that the women's work of childcaring has just began. Where she lacks good food intake to replenish the lost energy through breastfeeding, famine, lightness and other complications will occur, and the woman ends up becoming anemic, diseased, running mental, aging faster and dying.

It is important to state here too, that some women have adequate food supplements but lack the knowledge of caring for themselves after childbirth. That is why they either overeat, refuse to exercise, or minimally rest. The end result in such women is usually obesity, hypertension or stress. Such things open the gate to faster aging in women than in men.

\section{PSYCHOLOGICAL OUTFIT}

Related closely to childbirth is the psychological outfit of a woman. Naturally, a woman's life is complete when she has cordial relationship with her God and fellowmen. Where cordiality is completely lacking, women develop negative psychological fit whether married or single.

Some married women get worried to the point of psychological breakdown when their husbands are not stable. Family problems that are social, economic and psychological in nature tend to exert a lot on women. Unresolved quarrels are dangerous to women's psychological health, pushing them to age faster than their male counterparts. Internal psychological problems express on the body, thus, accelerating the aging process.

The third point about a woman's psychological aging is that her work in the home is like the work of the Holy Spirit. It is the woman that plans the meals, cooks or supervises and makes sure there is food on the table. The working class women have additional responsibilities Of attending to the office work and keeping the house. The husband expects to eat at the appropriate time, the children must be attend to as well as their father, visitors and household including the extended family demands must be met. The woman acts as a peacemaker in the home, place of work and community. All these take thinking, feeling and action which wear her out at the end of the day, by draining/sapping women's strength, time and energy. Except they are supported, they can grow old faster than their male counterparts

The trauma experienced by women at the loss/demise of their husbands is another fact related to psychological aging. In some cultures, widows are accused of killing their husbands. What follows thereafter, by way of punishment, is a chain of in-human treatments, and her in-laws could pack all that belonged to the family, leaving the poor widow with an empty house to take care of the children. Should such women resist, they are given a thorough beating. This practice adds to the already experienced loss of spouse and ages women faster than men. 


\section{INTERNATIONAL JOURNAL of RESEARCH -GRANTHAALAYAH

\section{COUNSELING TIPS TO SLOW DOWN THE RATE OF AGING}

Counselors have a duty to create awareness among their clients with counseling tips that can slow down aging in both women and men. Knowing fully well that aging comes naturally and artificially, one needs to take steps to accept the natural aging and age joyfully but slow down the circumstantial aging or avoid it where possible. The following are the counseling tips to postpone aging:
a. Diet
b. Exercise
c. Good grooming
d. Album collection and usage
e. Recreational engagement
f. Sleep and good rest
g. Good intra-personal and inter-personal relationships
h. Waiting on God

\section{DIET}

Derek Liewellyn - Jones (1998) suggests that as women grow older, they need to eat less fat and sugar, eat moderate proteinous food but eat more cereals, vegetables and fruits. To avoid anemia, pregnant women are supposed to eat a balanced died that would sustain healthy growth of the fetus as well as maintain good health.

The same type of diet but a bit increased in milk quantity is needed by breastfeeding mothers. It is important to avoid overeating that could make one become obese fostering aging devices. Proper dieting will slow down aging in women irrespective of their natural seeming disadvantage in childbirth that could hasten their aging. Every woman should be conscious of what she eats and drinks if she is to age slowly.

\section{EXERCISE}

To look good and healthy, every woman needs exercises in her life-time. There are graded exercises for the young, middle-aged and older women. It is the responsibility of the counsellor to emphasis the importance of exercising for good blood circulation and burning out excess fat. For relaxation and stress management purposes. each woman needs to know that after giving birth, graded exercises to help her return to normalcy are needed. These could range from walking about in the room to hasten the Lochia discharge during the first few days of delivery to cycling or running on one spot in the house if she cannot go out. 


\section{INTERNATIONAL JOURNAL of RESEARCH -GRANTHAALAYAH

\section{GOOD GROOMING}

Looking good and feeling good can be derived from good grooming. It pleases the soul and adds confidence when we are commended for our appearance. There is need to keep clean at all times and feel good because it relaxes and reduces stress and distress, and tension. Women and men who are paid compliments about how good they look cannot help but put on a smile, feeling that they are still seen as worthwhile and young.

Good grooming entails washing one's clothes, and body, choosing the correct dressing modes, wearing cosmetics, (for those who desire), dying one's hair or wearing an appealing wig. A little regression here and there makes one feel young at heart and happy that he/she is accepted by his/her folks. Good grooming should be encouraged among all persons so that it can relax them and attract confidence while reducing feelings of abandonment which may lead to faster aging.

\section{ALBUM COLLECTION AND USAGE}

Denga (1996) suggested strongly in his work on gerontology that album collection can go a long way in making the aging persons feel happy. The collection should include those photographs taken during their infancy, childhood, adolescence, young adulthood into middle age to the present time. This collection of one's photographs could revive or bring forth good memories of those vital days in life to challenge the present feelings of loss of energy, smooth and lovely hair, body-build and activities one used to love doing. Photo albums can be used to neutralize and ameliorate bad feelings of aging for those who are already old and have lost their youthful, looks.

\section{RECREATION}

The activities that one loved to undertake during his/her spare time in youthful days can be revived to suit the period of aging. The important thing in recreation is to change from one activity to the other in a most convenient way. One person's hobby may be gardening, another may be reading, sporting, travelling and others. Individuals should be encouraged to engage in activities that give them pleasure in order to avoid psychological breakdown which could accelerate aging. Changing one's environment once in a while could be of great help.

\section{SLEEP AND REST}

The need for sleep and rest should be emphasised if women and men are to slow down their rate of aging. When we sleep, our body rests and derives a special treatment in repairing and adjusting the troubled parts. All work without enough sleep and rest will arouse tension which may facilitate faster aging. Adults need at least five hours of sleep in a day irrespective of individual differences.

To encourage sleep Bako (1998) says the bed needs to be made comfortable. Neatness of the room too may attract one to sleep. It is also helpful to learn to relax, rest and sleep sufficiently. 


\section{INTERNATIONAL JOURNAL of RESEARCH -GRANTHAALAYAH

\section{Good Intra-personal and Inter-personal Relationships.}

Counsellors should encourage people wherever and whenever possible to accept themselves and live in peace with themselves in order to reduce internal combustion. This will enable individuals to think of others and relate to them as human beings. Self acceptance, love and peace will definitely attract friendship from others. There is a need to forgive oneself as well as forgive others their offences because God has forgiven us through Jesus Christ his only Son. When we forgive, we are at peace with ourselves, others and God. It postpones aging for the fact that instead of waste of energy to be sad, quarrel, fight and be distressed, we live to love, care and hope for the best.

\section{WOMEN (GENDER) ISSUES IN AGEING: AFRICAN PERSPECTIVES}

In the USA, a man's average life span is more than five years shorter than a woman's. Different hormone levels and life-styles choices may help explain the disparity. Over the past half century, life expectancy in the U.S.A. has slowly but steadily risen year after year. The main reasons for this trend are dramatic advances in medical diagnosis and treatment as well as changing American lifestyles with new emphasis on healthier diets and regular exercises and its declining dependence on mankind. One thing though has not changed: the gender gap in life expectancy. People, both sexes are living longer, but the gains in women's life expectancies have outpaced those of men.

In 1930 the average life span for American women was 61.6yrs and average for men was 58.1 yrs. By 2002 the average female and male life spans had risen to 79.9 and 74.7 years respectively. In other words the gender gap is now 50 per cent greater than it was 70 years ago (Simon, 2004).

This impressive difference is responsible for the striking demographic characteristics of older Americans. One-half of all women older than 65 are widowers and widows out number widowers three to one. At age 65 for every 100 American woman there are only 70 men. At age 83 there are only 38 men for every 100 women.

The gender gap is not unique to America. Every country with reliable health statistics reports that women live longer than men. The longevity gap is present both in industrial societies (79 versus 73 years in Western Europe and Australia) and in developing countries 54 versus 51 years in Sub-Saharan Africa). It is a universal phenomenon that suggests a basic biological difference between the ageing processes in males and in females.

Doctors are not sure why women live longer but it is likely that many factors contribute to the gender gap. Males differ from females from the moment of conception. It's all in the genes (the hereditary material, DNA). The male Y chromosome begins the process of sexual differentiation in the second trimester of pregnancy, when the fetal testicles secrete the male hormone testosterone. The importance of fetal hormones in determining sexual characteristics is obvious, but their role in influencing longevity is not clear. Still new research suggests that events during 


\section{INTERNATIONAL JOURNAL of RESEARCH -GRANTHAALAYAH

fetal life can affect health in adulthood. For example studies have shown that a low birth weight often caused by poor nutrition during pregnancy increases a man's risk of heart attack and stroke in adulthood. So it is conceivable that the levels of sex hormones at the very beginning of life also might influence events at the very end of life.

\section{SEX HORMONES: ESTROGEN AND TESTOSTERONE}

The longevity gap makes its first appearance in embryonic life itself. Sperm cells that contain a $\mathrm{Y}$ chromosome can out swim sperm bearing an X; as a result 115 males are conceived for every 100 females. But for reasons that are not quite understood, male embryos are more likely to miscarry than female, so that boys out number girls by only 104 to 100 at the time of birth.

At adolescence when testosterone kicks in, boys start behaving like men . The result is motor vehicle accidents, and other violent behaviours that send male death rate soaring to three times the female rate between 15 and 24. By age 25 females out number males and the gender gap keeps widening with each subsequent decade of life.

The difference in estrogen and testosterone levels between men and women is the simplest way to account for the gender gap. During their reproductive years women are much less likely than men to suffer from heart disease.

Estrogen makes the difference; the female hormones lower Low Density Lipoprotein (LDL) "bad cholesterol" and raises High Density Lipoprotein (HDL) "good cholesterol". After menopause, estrogen levels drop. LDH rises and HDL falls. It is not surprising that heart disease is a leading cause of death in older women as well as in older men. But women who take estrogen (hormone replacement therapy, HRT) after menopause have about 50 per cent fewer heart attacks. They also benefit from similar decrease in strokes as well as reduced risk of colon cancer and possibly Alzheimer's disease. Even without HRT, women have high levels of estrogen for three to four decades between puberty and menopause, that's up to 40 years more than men. This helps to explain the gender gap.

Men have less estrogen and much more testosterone. Produced by the Leyding cells of the testicles, testosterone rises to high levels during fetal life and plays a crucial role in developing the male genital organs. After that work, the hormone falls to low levels by one year of age and remains low until puberty, when it surges up to adult range. Testosterone remains steady until about 40 years when it begins slow steady decline that averages about one percent a year.

Testosterone makes the man, the hormone is responsible for the large muscles, strong bones, deep voice and receding hairlines that characterise the masculine gender. It is essential for sperm production and fertility. Testosterone also contributes to the aggressive behaviour patterns that typically distinguishes men from women. But surprisingly this hormone is like a doubled-edged sword. The large doses of the hormones (androgens) used illicitly by some athletes are hazardous causing aberrant behaviour, liver tumours, sterility and heart disease. New evidence suggest that 


\section{INTERNATIONAL JOURNAL of RESEARCH -GRANTHAALAYAH

even the normal levels of testosterone by the body may increase risk of suffering a lifeshortening disease. The prostate is an obvious example. The prostrate is a male sex accessory gland at the neck of the urinary bladder. In the prostate, testosterone is converted to dihydrotestosterone (DHT), the hormone that causes up to 80 percent of men to develop enlargement of the gland known as benign prostatic hyperplasia (BPH) as they age. The enlarged prostate does not shorten life but it squeezes the urethra which slows urination. DHT is also the hormone that causes prostate cancer that kills about 3 per cent of American men (Simon, 2004).

The effects of testosterone on the heart and circulation are more complex. In high doses, the hormone can lower levels of HDL cholesterol. But in physiological doses testosterone does not have a major effect on blood cholesterol levels. Men cannot change their chromosomes and very few would change their hormones even in the quest for longevity. But men can catch up with women by refraining from some of the lifestyle choices that add to the gender gap.

\section{SMOKING AND ALCOHOL}

Before 1960 smoking was far more prevalent among men than women in the USA. In 1955, 56.9 per cent of adult men were smokers compared to only 28.4 per cent of adult women. Since then the smoking rates have converged: the prevalence among women peaked at 33.9 per cent in 1965 and slowly declined to 20.7 per cent by 2001 , but over the same period the rate among men plummeted to 25.2 per cent according to the centers for Disease Control and Prevention. If smoking is one of the causes of the longevity gap, why is the gap getting larger even as smoking rates have equalized? It is because smoking kills slowly. People who start smoking today will pay a steep price for their habits later in life.

Like smoking, alcoholism is traditionally a male problem that is increasingly shared by women. Small to moderate alcohol protects a man's health, reducing the rate of heart disease. But heavy drinking and addiction shorten life, increasing the incidence of hypertension, stroke, liver diseases, accidents and various cancers.

\section{AGING SUCCESSFULLY}

"Every man", writes Jonathan Swith, desires to live long, but no man would be old"

Faced with ever present tick of the clock, can a healthy middle-aged man tell if he is likely to remain free of the disabling diseases that often tarnish the golden years? To find out, scientists evaluated 6,505 men between ages 45 and 68 who were in good health when the study began in the mid-1960s. The researchers tracked the men for nearly three decades. Of the men who survived to reach ages between 71 and 95, 40 percent remained free of both physical and cognitive impairment. The best predictors of successful aging were low blood pressure, low blood sugar, abstinence from tobacco and not being obese. It's a short and simple list - and it presents a set of goals that most middle-aged men can achieve with measure as simple as proper diet and regular exercise. 


\section{INTERNATIONAL JOURNAL of RESEARCH -GRANTHAALAYAH

\section{Why do women live longer than men?}

The explanation is complex, depending on both biological and behavioural differences between the sexes. In today's changing world, women seem to be acting more like men, when it comes to health, at least it's a step in the wrong direction.

\section{Dying and Death: The last Transition}

The primary goal of this concluding chapter is to help people realise that the reality of death can serve as a focal point for a more enjoyable, productive, contributive and fulfilled life. Each day in our lives becomes especially meaningful only after we have fully accepted the reality that someday we are going to die. We can then live each day to its fullest, as if it were our last day. Our mortality provides us with a framework from which to appreciate and conduct our lives. It should help us prioritize our activities so that we can accomplish what we want to accomplish (in our academic work, our professions, our relationships with others, our recreation) before we die. Quite simply, death gives us our only absolute reason for living.

\section{LIFE STYLES AND CONDITIONS THAT PROMOTE PREMATURE AND UNHEALTHY AGING}

The following life styles and conditions are major factors that promote premature/unhealthy aging:

Wrong Eating or Improper Dieting: This abnormality could cause heart attack. One could be said to diet right, if there is harmonization in the type and quantity of food taken with the type of job one does. The inability to synchronize the type of job with type and quantity of foods taken may lead to fat deposition in the body as well as increased blood volume and weight gain, these ultimately lead to unhealthy heart condition.

High Cholesterol: high cholesterol value in the body is hazardous. It has been linked to several heart diseases that have claimed many lives. It is advisable to regularly check cholesterol level in the system.

Lack of Exercise: Research and studies have shown higher incidence of heart attack and allied health problems among sedentary workers than in physically active people. Regular physical exercise puts one in a perfect physical and mental state of health.

Excessive Intake of Alcohol: Excessive intake of Alcohol leads to unhealthy heart condition. Alcohol encourages blockages of blood vessels by fats formed through its conversion; in effect alcohol in the body turns into sugar and if not used immediately is converted and stored as fat plagues in blood vessels thus obstructing the free flow of blood that could culminate in heart problems.

Smoking: Besides causing cancer, it has been linked to causing heart problems. The risk of getting heart attacks is proportional with the amount or quantity of cigarettes smoked, larger quantity-higher risk and vice versa. 


\section{INTERNATIONAL JOURNAL of RESEARCH -GRANTHAALAYAH

Intake of Caffeine: Caffeine is contained in kola, coffee, regular tea, and carbonated drinks. They should be avoided as much as possible.

Hardening and Thickening of Blood Vessels: This is otherwise known as calcification of blood vessels. Hardening and thickening of blood channels leads to reduced elasticity of the channels which consequently inhibit free and normal flow of blood. This incapacitates the heart and brings about its inefficiency and failure.

Rate of calcification i.e. Hardening, thickening and inelasticity of blood vessels is a function of age and salt intake.

Obesity and Overweight: One is obese if the BMI (body mass index) is above 30 and overweight if the BMI is between 25 and 29. Both Obesity and overweight put excess load on the heart stretching it beyond its capacity, consequently, the heart suffers reduced resistance to fatigue, stress and ultimately shortening of life span.

Depression: Studies have linked prolonged depression to increased risk of heart attack.

Malformation of Blood Vessels and Other Heart Components: Naturally malformed blood vessels and other components of the heart could bring about malfunctioning of the organ which could manifest in different types of ill health.

Genetic/Hereditary Factors: There are families where certain health problems such as diabetes, High Blood Pressure and heart attack run. Anybody that finds himself/herself in such families had better be well equipped on check and control measures early in life before it gets too late.

Increased Blood Volume: This could cause heart problems. It occurs as a result of the inefficiency or malfunctioning of the kidneys as well as overweight. The inefficiency of the kidneys result in some waste materials being left in the blood stream thus increasing the volume of the blood and consequently affects its free flow. It may result in blood clotting and blockage of the channels.

\section{Premature Aging:}

Premature ageing occurs when an individual starts to develop qualities supposedly exclusive of the older people, e.g growing of grey hairs, wrinkles, and developing degenerative diseases/conditions that show characteristics of old age.

The causes of early ageing are:

i. Weight gaining, unhealthy life style, abuses during younger age

ii. Smoking, stress, wrong eating, sedentary life, ignorance, poor emotional, mental and social unhealthy life. 


\section{INTERNATIONAL JOURNAL of RESEARCH -GRANTHAALAYAH

\section{CAUSES OF WRINKLES}

Smoking, Overweight, Sickness, strong body creams and soap; lack of exercise, Exposure to chemicals and sunlight

\section{How to Avoid Wrinkles (folds or lines in the skin)}
a. Eat a lot of fruits
b. Avoid too much carbohydrates or starchy foods.
c. Do work that could make you sweat.
d. Take more Vitamin A and B2 rich foods. petunias etc.
f. Avoid harsh chemical and cosmetics.
g. Shield yourself from intense sunlight
h. Water used for bath should be lukewarm (older population)
i. Always smile and maintain a pleasant disposition
j. Exercise and massage your face daily

e. Eat plenty foods that contain Flavonols. Flavonols is a component found in some foods, it helps to slow down the ageing of cells. Flavanols could be found in tomatoes, onions, tea,

\section{AGING: LETS SLOW IT DOWN}

We all have two (2) ages. There is our Chronological age, which involve the celebrating of birthdays and passing of years, and our biological age, which reflects the rate at which we are getting older. Everybody ages at the same chronological rate, but people do not age at the same biological rate. We shouldn't think of growing older as a time of physical degeneration, senility or becoming cantankerous. Our aim should be to maximize our vitality, doing what contributes to optimum health, so we can maintain our zest for living.

Aging is not a disease but a natural process.

\section{AGING WITHOUT GROWING OLD}

Cell function is the basis of all life. As we grow older, trillions of body cells reproduce countless times and in the course of reproduction gradually change. To reduce biological aging, our goal is to maintain the reproduction of our cells with minimal deterioration or change.

Every cell has a limited life. It performs its function in the body, then reproduces itself and dies. At any given time, thousands of your cells reproduce slowly, while skin cells reproduce approximately every ten hours. Only one type of cell doesn't follow this pattern - the cells of the brain. You were given your lifetime supply of brain cells at the time of your birth. When these cells become worn out and die, some authorities report they are never replaced. Others are now reporting that they can regenerate. Scientists tell us that by age 35, a person is losing 


\section{INTERNATIONAL JOURNAL of RESEARCH -GRANTHAALAYAH

100,000 brain cells a day. I always wonder who is counting! Fortunately, whether they can regenerate or not, the initial supply is so great that this loss is scarcely noticeable.

\section{DO WE HAVE CONTROL OVER AGING?}

Much of ageing has to do with our life-style choices and personal environment. The good news is that this is something over which we do have some control. A number of things cause damage to our cells, such as ultraviolet light, x-rays, smoking, alcohol, lack of exercise, chemicals in our foods, processed or oxidized fats, wrong feeding, unhealthy life style, toxins in our system, abuses and many other factors. But damage to cells can be minimized in many ways.

Exercises: One of the very important anti-ageing remedies is regular moderate exercises. Sedentary life is an invitation to premature ageing. The more you exercise the body, the healthier it becomes. Exercise needs not be vigorous or rigorous but should be regular. Any of the following exercises could be considered and practiced: Road walk, Table tennis, Cycling, Golf (non-competitive type); dancing, jogging, swimming for about 20-30 minutes per day up to 4 times a week.

Massage and Relaxation: Advanced individuals should endeavour to practice massage as a routine. Always relax thoroughly and fret over nothing, as God takes care of all things for those who believe in Him. The bible declares in Philippians 4 verse 6:

"but in everything by prayer and supplication with thanksgiving, let your requests be made known unto God".

Nutrition: Thomas Edison once said "The doctors of the future will give no medicine, but will interest their patients in the care of the human system, with diet, and the dwelling of diseases may no more be in the body. People who aspire to live long and live healthy should by deliberate action opt for taking balanced naturally based diets.

Anti-Oxidants: These are the body scavengers of healthy-ageing opponents called free radicals. Most people are familiar with at least some of the benefits attributed to such popular antioxidants as Vitamins A, C, D, Vitamin E, Beta carotene, Selenium, gernodema, ginseng, etc.

Free radicals are defeated essentially by being trapped, or isolated and not allowed to seek out electrons from neighbouring cells by anti-oxidants. Etukudo (2014) asserts that we are constantly generating free radicals through normal physiological, biological and environmental processes. We are always constantly being exposed to free radicals through exposure to such things as exhaust fumes, cigarette smokes, electricity- generating-sets fumes, nitrates in hard (bad) water, chemical and processed foods, drugs and through so many other man's activities of day to day routines. As Etukudo (2014) puts it, the free radicals are destructive substances capable of disrupting the architecture of the cell membranes. They have been implicated as responsible for accelerated aging process and on set of cancer. 


\section{INTERNATIONAL JOURNAL of RESEARCH -GRANTHAALAYAH

\section{DAMAGING EFFECT OF FREE RADICALS}

- Free radicals are responsible for the following effects in our body system:

- Damage to cells

- Protein synthesis is impaired

- Protein becomes cross-linked and tangled

- Tissues become less pliable

- Arteries incur damages leading to arteriosclerosis

- Genetics materials (DNA/RNA) is dammed leading to cancer

- Impairment of natural repair and healing process

- Age pigments accumulate thus drowning the cells and this prevent optimal function. In general, all Age - Related Syndromes (ARS) are facilitated by presence of free radical including folds wrinkles, sags, weakness, Alzheimer, Parkinson disease, cardio-vascular and cardio-pulmonary

- diseases.

- Damage to vision cells which increases the chances of cataract and glaucoma development.

- Degrade tissue strengthening collagen with the joints, muscle and bone that speed up ailments like arthritics and rheumatism.

Infact, free radicals have been implicated as responsible for more than 80 diseases and the older one becomes, the higher amount of free radicals accumulated by the body.

\section{RECOMMENDATIONS}

For healthy ageing the following are recommended:

Regular exercise is strongly recommended. Though one is expected to be involved in regular exercise before reaching old age, for the elderly it is necessary for active healthy ageing. Group exercises is most rewarding as it helps to establish a routine and the social interaction point to reduce stress isolation and depression common at this age.

Ministries of Sport, Social Welfare, Health and other related authorities should encourage and promote the formation of such exercise groups. Professionals should assist to educate people on the type of exercise most suitable and beneficial to various groups. Individuals should also form and join exercise clubs manned by trained professional instructors. One of the centers that offer exercise services is VISA HEALTH FITNESS RECREATION CENTRE at temporal sport complex Nnamdi Azikiwe University, Awka directed by the author with a team of other professionals. Contact-08034936434; drobyokonkwo@yahoo.com

It must be remembered that exercise cannot be stored (e.g. doing one week's exercise in one day). For exercise to be beneficial, it has to be regular and continuous. 


\section{INTERNATIONAL JOURNAL of RESEARCH -GRANTHAALAYAH

Health checks and medical check-ups help to detect early signs of diseases, when they can be treated and cured. These checks are essential and must be carried out for healthy ageing. It is ideal to have community-based-health-enhancing centres and programmes to enable people to acquire information on health- risk factors. Health checks and screening can be carried out at such centers.

Healthy diets help to prevent diseases. One should avoid being undernourished by not eating enough food or being malnourished by having an unbalanced diet. Food does not have to be expensive to be balanced. Take food high in fibre and low in cholesterol, animal fat and salt. Take a lot of fresh fruit and green vegetables plus a lot of water. Old people should ensure that they are active and productive members of their communities so that society can continue to benefit from their years of experience. They should be encouraged by the community to continue to be useful members and not as something that has been spent which is good only for the dustbin.

Retirement with delayed or without payment of pension and gratuity by governments in Africa (particularly in Nigeria) leads to unhealthy aging. Some retirees fail to get their pension or gratuity many years after retirement. These are people with families who have given the best part of their lives in the service of the nation. We should be aware of the health implications of such actions. As the breadwinner is affected the implications spread to all members of the family. The actions of such governments and some companies and parastatals send some of their retired staff to early death.

Senators and other legislators should speak out against such practices and make laws to protect these helpless senior citizens. As each person gives at least three months' notice of retirement, the employer should pay their employee his/her entitlements as soon as the retirement is effected (i.e. on the effective date of retirement). The practice of sudden, unexpected and unplanned retirement (where no offence is committed) without adequate compensation or with no compensation at all forces one to start life afresh elsewhere is destroying the society. Many of such people may never reach old age and healthy ageing will not even arise.

It is very healthy to maintain our mental and emotional health at this age. Be prepared to learn to accept what you cannot change, strive to change what you can and pray for divine intervention for what is beyond human capacity. See the "good" and the "bad"; the "plus" and the "minus"; the "pains" and the "pleasures" as part of life. As Christians we must always remember that without cross, there is no crown. Always keep a free mind, crack jokes, laugh lavishly, keep pleasant disposition. Create constant opportunity to share with others - in such area like recreation, feeding, prayers, sporting, dance, disappointment/problem solving, and so on, in other to boost social health which enhances emotional and mental stability.

\section{CONCLUSION}

Women and men alike age chronologically, socially and physiologically. Nevertheless, research by Brandstrader (2000) has revealed that women now outlive their male counter-parts in the 


\section{INTERNATIONAL JOURNAL of RESEARCH -GRANTHAALAYAH

United States of America in terms of longevity. It has been discovered that women have a chance of living up to 100 years more easily than men. This could be due to good medical attention, balanced diet intake and positive habits formed during youthful years that span through the old age to keep one going and aging more slowly.

Due to some natural phenomena like monthly cycles, childbirth and psychological experiences, women stand a chance of aging faster than men. But thank God for the advancement in medicine, efforts by various governments to eradicate poverty, and the creation of awareness through counselling to help women postpone growing old faster than men.

Ageing is an inevitable process in life. It depends on individual decision and life style to make it enjoyable. This is what I refer to as GRACEFUL AGEING. 83 year old Bishop Emeritus of Sokoto Diocese- Bishop Kelvin Aje has this to say

"Old age is a stage in life that people should look forward to, that is why I am enjoying my life at this stage. I pray, plan and hope to enjoy my life even in the next 10 years according to God's mandate. You should prepare your old age at a younger age. Plan for what your age should be in 20 years time. So if for instance you are 30 years, plan what your life should be at 50 years. If you are 60 years, plan for what your life should be at 80 years and so on. What is your life now?; what is it supposed to be? and what difference can you make to improve it?" Aje concludes.

Naturally as age increases, the risk of chronic diseases and disabilities increases too. However, aging can take place without the disabling chronic diseases, if one is informed of what to do and does it with commitment. That is what I term "AGING WITHOUT GETTING OLD" in one of my books. Healthy aging means being able to maintain independent, happy and fulfill living for as long as possible in old age. That is aging without serious challenges of disability or chronic diseases and without obvious signs of old age.

Life is good! So says IGI. Make conscious effort by eating the right food that ensures good health. Many people still believe that wealth is the only indices of good health and happy living. On the surface, most wealthy people put up air of happiness, without the right information on how to use their wealth to buy the right kind of food that ensures good health. Quality life and wellness shall continue to elude them. The greatest fears of man are pain, disease and death. That is why you should not use your money to buy this problem in the name of buying food that may turn against your good health.

Just like "heavenly race," life itself is an individual race, so is "agingly race". With focus, will power, determination, dedication, concentration and attention, one can make it. Give your life the attention it deserves. No one has ever planted crops and left it without constant/regular attention and expect bumper harvest. On the other hand no one puts food on fire and goes sleep, wakes up after few hours and expects a wonderful meal. Lastly wise business men and women float their businesses with capital but put in more effort than the money initially invested to make their businesses grow. These are but just few illustrations. So my good audience, we do not have any luxury of time to wait until we are ready to act. The time is NOW! 


\section{INTERNATIONAL JOURNAL of RESEARCH -GRANTHAALAYAH

Social

\section{REFERENCES}

[1] Etukudo, M. H. (2014). Ant-oxidants: Sacrificial Lamb to free radicals. The 59 ${ }^{\text {th }}$ Inaugural lecturer of University of Calabar. Calabar, Nigeria. University of Calabar Press.

[2] McFarland, J. L. (2003). Aging without growing old. Florida, USA, Siloan Press.

[3] Okonkwor, Oby. C. N. (2013) Drug use and drug education in contemporary society. Awka. Heritage Publishing Ltd.

[4] Okonkwor, Oby. C. N. (2014) Eating to live or living to eat. Awka. Amaka Dreams Press. [5] Okonkwor, Oby. C. N. (2014b) Graceful Aging without sign of Old age. In HEALTH/FITNESS CORNER with Prof Oby Okonkwor (ed) Fides, April, 27-3 ${ }^{\text {rd }}$ May Pg. 18.

[6] Olowookere, J. (2002). Aging and the key to longevity. Ibadan. Divine Favour Press. [7] Taylor, S. T. (2013). Health Psychology. $\left(5^{\text {th }}\right.$ ed) NY. USA. McGraw-Hill Co. 